\title{
Religiosity and Spirituality: Is It an Appropriate Issue in Psychiatry and Psychotherapy? -Comparative Studies of Germany and South Korea
}

\author{
Eunmi Lee1,2, Klaus Baumann1 \\ ${ }^{1}$ Caritas Science and Christian Social Work, Faculty of Theology, Albert-Ludwig-University Freiburg, Germany \\ ${ }^{2}$ Center for Social Cohesion, Daegu Catholic University, Republic of Korea \\ Email: eunmi.lee@theol.uni-freiburg.de, Klaus.Baumann@theol.uni-freiburg.de
}

How to cite this paper: Lee, E. and Baumann, K. (2019) Religiosity and Spirituality: Is It an Appropriate Issue in Psychiatry and Psychotherapy?-Comparative Studies of Germany and South Korea. Open Journal of Social Sciences, 7, 300-310. https://doi.org/10.4236/jss.2019.73025

Received: January 30, 2019

Accepted: March 18, 2019

Published: March 21, 2019

Copyright $\odot 2019$ by author(s) and Scientific Research Publishing Inc. This work is licensed under the Creative Commons Attribution International License (CC BY 4.0).

http://creativecommons.org/licenses/by/4.0/

(c) (i) Open Access

\begin{abstract}
In patient-centred care, religious and spiritual needs and values of patients are increasingly underlined. The field of psychiatry and psychotherapy is no exception in this regard, so more attention and research are required. In addition to existing research, taking a further step, we would like to know whether there are any cultural differences in regard to staffs' religious and spiritual values, and their attitudes to deal with religious or spiritual issues in clinical settings. For that reason, comparative studies were conducted in Germany and Korea. As a result, we found that German psychiatric staffs have more positive perspectives on religion and related aspects than Korean, not only in their personal lives but also in therapeutic settings. Furthermore, some contradictions regarding religiosity and spirituality were shown in staffs' professional attitudes of both countries. Above all, in consideration of professional neutrality respondents are reluctant to handle such issues in therapeutic settings. For Korean psychiatric staffs, another important reason was that they are predominantly atheists or agonistics. German psychiatric staffs referred to have insufficient time. The kind of professionality which they are proclaiming to keep during the therapeutic processes is shown to be inadequate for several reasons. For genuinely wholistic care, more cross-cutural and in-depth studies are needed. Furthermore, professional self-contradictions deserve further attention and reflection, for the patients' sake.
\end{abstract}

\section{Keywords}

Psychiatric Staffs, Religious and Spiritual Values, Korea, Germany, Contradictions, Professional Neutrality 


\section{Introduction}

There has been an exponentially growing body of research in English-speaking journals on "Religion and Health", including mental health [1] [2] [3] [4]. The $1^{\text {st }}$ edition of the "Handbook of Religion and Health" [3] informed about more than 1200 research studies done between 1872 and the year 2000 . The $2^{\text {nd }}$ edition [2] then provides an additional appendix with more than 2100 original quantitative data-based studies conducted between 2000 and 2010. Koenig et al. [2] state "an enormous increase in attention paid to the topic by academic medical, sociological, public health, nursing, psychiatric, and psychological journals. There has literally been the birth of an entire new field, the field of religion, spirituality, and health." These remarks include manifold research concerning religious and spiritual needs and attitudes of patients in psychiatric and psychotherapeutic patient care, both in Germany and in Korea such research is still comparatively rare, notwithstanding increasing efforts in Germany [5] [6] [7] [8] [9]. These efforts in the meantime resulted into a Position Paper of DGPPN (German Society of Psychiatry, Psychotherapy and Neurology) first published in 2016 [10]. Among other recommendations, this position paper calls for more research both into religious and spiritual needs and attitudes of patients as well as professional staffs in psychiatry and psychotherapy, and into the implications for treatment. These recommendations strongly correspond to the research concept of our Freiburg research group created in 2009.

To our knowledge, there have not been similar studies in Korea yet with the exception of our survey started in 2015. Both Germany and Korea can be considered modern secular societies, which guarantee pluralism, freedom of sciences and religious freedom. They have different historic backgrounds and cultural traditions, while at the same time both of them are advanced industrialized and technologically leading economies, which imply cross-cultural encounters with their chances and challenges. All of these and more elements have their impact not only on mental health and mental disorders, but also on how psychiatric and psychotherapeutic professionals perceive patients as well as their mental conditions, and treat them accordingly.

As part of our research in both countries, we want to compare data from both countries. We would like to know whether there is any difference between German and Korean psychiatric staffs in regard to:

- personal religious and spiritual values;

- attitudes to handle religious or spiritual issues with patients.

\section{Methods}

\subsection{Materials}

First, the Duke University Religion Index (DUREL) was used to explore psychiatric staff's religious and spiritual values. This instrument, composed with five questions, measures extrinsic (organizational and non-organizational; separately one item) and intrinsic religiosity (three items). As a brief measure in- 
strument DUREL has been used in numerous international studies. Its psychometric qualities are also identified and confirmed by several studies [9] [11] [12].

Secondly, a questionnaire on Religion and Spirituality in Medicine: Physicians' Perspectives (RSMPP), developed by F. Curlin and his team in 2002 [13], was partially used to find out how health professionals react when religious and spiritual issues are brought up by their patients in psychiatric settings. Its producing processes as well as psychometric qualities are published in various papers [13] [14] [15]. In recent years, RSMPP has been utilized in various medical majors in diverse nations [16] [17]. Additionally, we asked participants, what kind of barriers they experience against handling religious and spiritual issues with patients.

For the first time, we translated these instruments into German. These were revised as well as checked by professionals. After the pilot study at Freiburg University Hospital, these instruments were further improved, esp. via comments of participants. In 2011, the nationwide study in Germany was conducted. Its results were published in several peer-reviewing academic journals as well as in the PhD thesis of the first author [18] [19].

In order to research in Korea, we translated our German version of questionnaire into Korean. With the purpose of comparison, we used the German version, not the original one. Nevertheless, during the translation process we checked parallel with the English original version. A bilingual master student (German and Korean) reviewed as well as improved the Korean version of questionnaire. Finally, it was reviewed by two Korean psychiatric professionals. All translating and retranslating processes were done following the recommended procedures, incl. back translation.

\subsection{Respondents}

To explore the viewpoints with religious and spiritual values between these countries in Asia and Europe, two main studies were planned, separately in Germany and Korea. They were conducted anonymously. All participants were informed about the purpose of our study as well as their right to withdraw at any time.

First, an anonymous survey was conducted among German staffs working in psychiatric departments of university hospitals and faith-based clinics in nationwide 16 cities. The medical director of each clinic had been asked, and distributed a paper-based questionnaire with our self-addressed envelopes to psychiatric and psychotherapeutic employees. The data collecting period was from October 2010 to February 2011. All in all, 21 clinics participated and 404 questionnaires were returned by post. The response rate was $24.43 \%(\mathrm{~N}=404$ of 1654).

In the case of our Korean study, six clinics in three cities were participated. A paper-based questionnaire was distributed to psychiatric staffs. The collection period was from April to May 2015. All questionnaires were collected through 
personal visits. A voucher (5000 won in Korean currency-about 3.80 Euro) was given to all participants who completed and submitted the questionnaire. The number of returned questionnaires was 281 . The response rate was $85.67 \%(\mathrm{~N}=$ 281 of 328). Incomplete responses were excluded, so consequently 581 questionnaires were included in the statistical analysis. A final response rate was $29.31 \%(\mathrm{~N}=581$ of 1982$)$.

\subsection{Statistical Analysis}

All data were analyzed with SPSS 25.0 for Windows. All responses were fundamentally analyzed for both countries according to demographic characteristics (incl. age, sex and occupation), basically using nonparametric tests. Significance level was set at $p<0.05$.

\section{Results}

\subsection{Demographic Characteristics}

On average, Korean respondents were younger than German respondents. After grouping according to units of ten years of age, differences were checked again. But, except for the age group 30 - 39 years, each age group showed a significant difference (data not shown). In regard to occupation, most of German participants were nursing staff or psychiatrists, while about $75 \%$ of Korean participants have nursing or other vocational work, esp. psychiatric social work. In detail, significant difference was shown with two groups, psychiatrists and other occupations, but not with psychotherapists or nursing staff. According to gender, there was no significant difference. Further information is provided in Table 1.

\subsection{Religious and Spiritual Values}

First, as to religious affiliations, German and Korean mental health professionals showed a significant difference. Almost $70 \%$ of German participants answered to have some religious affiliation, more than half of the Korean respondents do not $(p<0.001)$. Among respondents of both countries, reporting a religious affiliation, most of them were Protestants or Catholics (data not shown). Similarly, nearly $60 \%$ of German mental health professionals proclaimed to be a believing person, while more than $55 \%$ of Korean regarded themselves as non-believers ( $p$ $=0.001$ ).

Furthermore, we asked how often they go to religious or spiritual places (e.g. church or temple) as well as practice religious or spiritual private activities (e.g. prayer, meditation, reading bible) in order to know, how (and how differently) German and Korean psychiatric staffs may engage in religious or spiritual activities. According to analytic results, Korean health professionals were less engaged in religious or spiritual activities than German psychiatric staffs. Nearly $50 \%$ of Korean psychiatric staffs never go to church or religion-related places, while more than half of the German staffs do so at least once a year $(p<0.001)$. Although more than half of each national groups were seldom or even never active 
with non-organizational religious activities, still, this was true for about $20 \%$ more of, Korean respondents than German ones $(p<0.001)$. Further information can be found in Table 2 .

Furthermore, participants were asked about their intrinsic religiosity in three questions (of the DUREL). The answers in an ordinal scale were from 1 to 4 . The intrinsic religiosity was calculated as the sum of all three questions. All participants showed the intrinsic religiosity $\mathrm{m}=6.57( \pm 2.84)$. However, the score of German psychiatric staff is higher than of the Korean psychiatric staff. The intrinsic religiosity of German participants is $m=6.91( \pm 3.15)$, while Korean participants showed $\mathrm{m}=6.19( \pm 2.39)$. This difference is statistically significant $(p=$ 0.020). Detailed information is found in Table 3.

\subsection{Attitudes to Religious and Spiritual Issues}

What do psychiatric staffs think about dealing with religious and spiritual issues with their patients? Is there any cultural difference?

German participants definitely have more positive attitudes to handle religious and spiritual issues than Koreans. In contrast to Koreans, German mental health professionals think it is appropriate to ask or even discuss with patients about religions and related topics. However, this is limited to professional conversation. As to praying together with psychiatric patients, they were more critical than Korean staffs. Detailed information is described in Table 4.

\subsection{Barriers to Deal with Religious and Spiritual Issues}

Finally, we asked participants what kinds of barriers they perceive against integrating religious and spiritual issues into therapeutic settings. Here, participants could provide multiple answers. The most often mentioned answer was professional neutrality (see Figure 1), by both national groups. But the proportion was

Table 1. Demographic characteristics.

\begin{tabular}{|c|c|c|c|}
\hline \multirow{2}{*}{ Variable } & \multicolumn{3}{|c|}{ Values (\%) } \\
\hline & Germany & Korea & Significance $^{b}$ \\
\hline Absolute number & 307 & 274 & - \\
\hline Age (years) ${ }^{\mathrm{a}}$ & $40.05( \pm 10.91)$ & $33.94( \pm 9.39)$ & $p<0.001^{\star \star *}$ \\
\hline \multicolumn{4}{|l|}{ Sex } \\
\hline Female & $192(62.5)$ & $190(69.3)$ & $p=0.085^{\text {n.s. }}$ \\
\hline Malie & $115(37.5)$ & $84(30.7)$ & \\
\hline \multicolumn{4}{|l|}{ Occupation } \\
\hline Psychiatrist & $97(31.6)$ & $42(15.3)$ & \\
\hline Psychotherapist (incl. Psychologist) & $40(13.0)$ & $27(9.9)$ & $p<0.001^{\star * *}$ \\
\hline Nurse & $127(41.4)$ & $127(46.4)$ & \\
\hline Others & $43(14.0)$ & $78(28.5)$ & \\
\hline
\end{tabular}

${ }^{\mathrm{a}}$ Numeric results were rounded up to the nearest hundredth. ${ }^{\mathrm{b}}$ Significance level: ${ }^{\star * \star} \mathrm{p}<0.001,{ }^{\star *} \mathrm{p}<0.01$, ${ }^{*} \mathrm{p}<0.05$. 
Table 2. Extrinsic religiosity.

\begin{tabular}{|c|c|c|c|}
\hline \multirow{2}{*}{ Variable } & \multicolumn{3}{|c|}{ Values $^{\mathrm{a}}(\%)$} \\
\hline & Germany & Korea & Significance $^{\mathrm{b}}$ \\
\hline \multicolumn{4}{|l|}{ Denomination } \\
\hline $\begin{array}{l}\text { Having no } \\
\text { religious affiliation }\end{array}$ & $98(31.9)$ & $144(52.6)$ & $p<0.001^{\star *}$ \\
\hline $\begin{array}{c}\text { Having a } \\
\text { religious affiliation }\end{array}$ & $209(68.1)$ & $130(47.4)$ & \\
\hline \multicolumn{4}{|l|}{ Proclaim } \\
\hline As a non-believer & $129(42.0)$ & $152(55.5)$ & $p=0.001^{\star *}$ \\
\hline As a believer & $178(58.0)$ & $122(44.5)$ & \\
\hline \multicolumn{4}{|l|}{ Churchgoing } \\
\hline More than once a week & $13(4.2)$ & $13(4.7)$ & \\
\hline Once a week & $17(5.5)$ & $39(14.2)$ & \\
\hline A few times a month & $33(10.7)$ & $17(6.2)$ & $p<0.001^{* * *}$ \\
\hline A few times a year & $98(31.9)$ & $35(12.8)$ & \\
\hline Once a year or less & $97(31.6)$ & $40(14.6)$ & \\
\hline Never & $49(16.0)$ & $130(47.4)$ & \\
\hline \multicolumn{4}{|l|}{ Private religious activities } \\
\hline More than once a day & $17(5.5)$ & $6(2.2)$ & \\
\hline Everyday & $42(13.7)$ & $25(9.1)$ & \\
\hline More than two times a week & $35(11.4)$ & $26(9.5)$ & $p<0.001^{* * *}$ \\
\hline Once a week & $19(6.2)$ & $11(4.0)$ & \\
\hline A few times a month & $36(11.7)$ & $17(6.2)$ & \\
\hline Seldom or never & $158(51.5)$ & $189(69.0)$ & \\
\hline
\end{tabular}

${ }^{a}$ Numeric results were rounded up to the nearest hundredth. ${ }^{\text {S}}$ Significance level: ${ }^{* *} p<0.001,{ }^{* *} p<0.01$, * $p<0.05$.

Table 3. Intrinsic religiosity.

\begin{tabular}{cccc}
\hline Variable & \multicolumn{3}{c}{ Values $^{\mathrm{a}}$} \\
\cline { 2 - 4 } & Germany & Korea & Significance $^{\mathrm{b}}$ \\
\hline $\begin{array}{c}\text { Religious beliefs influence } \\
\text { whole approach to life }\end{array}$ & $2.50( \pm 1.10)$ & $2.20( \pm 0.91)$ & $p=0.001^{* *}$ \\
$\begin{array}{c}\text { Try to carry religion into } \\
\text { other aspects of life }\end{array}$ & $2.23( \pm 1.06)$ & $2.16( \pm 0.85)$ & $p=0.632^{\text {n.s. }}$ \\
$\quad \begin{array}{l}\text { Experience } \\
\text { God's presence }\end{array}$ & $2.29( \pm 1.14)$ & $1.81( \pm 0.84)$ & $p<0.001^{* *}$ \\
\hline
\end{tabular}

${ }^{\mathrm{a}}$ Numeric results were rounded up to the nearest hundredth. ${ }^{\mathrm{b}}$ Significance level: ${ }^{* *} p<0.001,{ }^{* *} p<0.01$, * $p<0.05$. 
Table 4. Attitudes to religious and spiritual issues.

\begin{tabular}{|c|c|c|c|}
\hline \multirow{2}{*}{ Variable } & \multicolumn{3}{|c|}{ Values $^{\mathrm{a}}$} \\
\hline & Germany & Korea & Significance \\
\hline $\begin{array}{l}\text { In general, it is appropriate for } \\
\text { psychiatric professionals to inquire about } \\
\text { a patient's religion and/or spirituality. }\end{array}$ & $3.08( \pm 0.85)$ & $2.40( \pm 0.78)$ & $p<0.001^{* * *}$ \\
\hline $\begin{array}{l}\text { In general, it is appropriate for } \\
\text { psychiatric professionals to discuss } \\
\text { religious/spiritual issues, when a patient } \\
\text { brings them up. }\end{array}$ & $3.39( \pm 0.67)$ & $2.53( \pm 0.72)$ & $p<0.001^{* * *}$. \\
\hline $\begin{array}{l}\text { In general, it is appropriate for } \\
\text { psychiatric professionals to talk about his } \\
\text { or her own religious beliefs or } \\
\text { experiences with a patient. }\end{array}$ & $1.88( \pm 0.81)$ & $1.97( \pm 0.72)$ & $p=0.082^{\text {n.s. }}$ \\
\hline $\begin{array}{l}\text { In general, it is appropriate for } \\
\text { psychiatric professionals to pray with a } \\
\text { patient together. }\end{array}$ & $1.53( \pm 0.77)$ & $1.89( \pm 0.73)$ & $p<0.001^{* * *}$ \\
\hline
\end{tabular}

${ }^{\mathrm{a}}$ Numeric results were rounded up to the nearest hundredth. ${ }^{\mathrm{b}}$ Significance level: ${ }^{* *} p<0.001,{ }^{* *} p<0.01,{ }^{*}$ $p<0.05$.

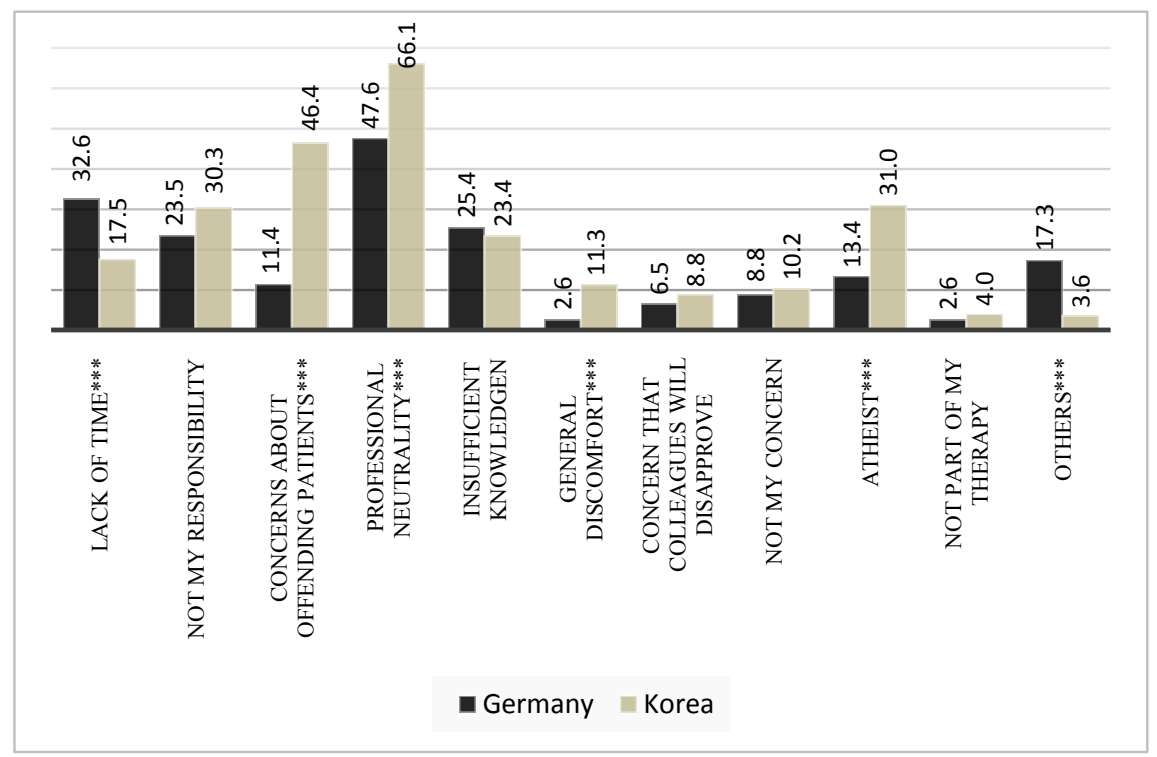

Figure 1. Barriers to deal with religious and spiritual issues. Significance level: ${ }^{* *} p<$ $0.001,{ }^{* *} p<0.01,{ }^{*} p<0.05$.

significantly different between Korean and German respondents $(66.1 \%$ vs. 47.6\%: $p<0.001)$. German psychiatric staffs reported the lack of time as the second obstacle, whereas Korean psychiatric professionals mentioned their concern that religious and spiritual factors could offend psychiatric patients (respectively $p<0.001)$.

\section{Discussion}

By this comparative study, we obtained some meaningful findings. They are fol- 
lowing:

First, German mental health professionals seem to be significantly more familiar with religious and spiritual issues than Koreans. Moreover, this is true not only in terms of personal meaning, but also in clinical settings. Although Korea is regarded as one of the multi-religious countries in Asia, religious and spiritual issues are generally excluded in psychiatric clinical settings. Some mental health professionals are religious or spiritual on their own though. Nevertheless, they (want to) keep religious or spiritual issues strictly apart from therapeutic settings. In addition, Korean mental health professionals commonly consider religions and related elements as an insalubrious influence factor. In contrast to Korea, German mental health professionals considered that such issues are not very important, therefore they prefer that someone else could handle them, as they themselves are having no time and enough other important tasks.

Secondly, for most of Korean psychiatric professionals the topic, religiosity and spirituality in mental health, appears to be simply not imaginable. While German psychiatric health professionals regarded religious and spiritual issues as a trifling theme, Korean considered them unnecessary or even insalubrious. In contrast to German professionals, many of Korean staffs do not understand what exactly pastoral (and, by extension, spiritual) care is, with the exception of associating it (more or less mistakenly) with missionary work.

In connection with these findings, we can see that some contradictions are coming to the front. Namely, respondents answered that they should keep their professional neutrality during therapeutic processes, therefore it is inappropriate to handle religious and spiritual issues. This attitude was shown more strongly by Korean psychiatric respondents. Many of Korean respondents mentioned that religion and therapy are completely separate. What can they do, however, when religious and spiritual issues come up with patients in the therapeutic process? Should they exclude such issues, which are possibly relevant for the patients' behavior and mental health? What would "neutrality" mean in this regard, if it does not mean to ignore such relevant aspects of their patients' psychological condition? Furthermore, Korean psychiatric respondents answered that they are not willing to handle religious and spiritual issues, as they are atheists or such issues are not important for themselves. Although there are deep historical roots in behavioral sciences for such attitudes [20], this is not really a professional reason, but rather an anti-religious bias. It is obviously in conflict with the professional neutrality which on the other hand they sincerely want to live up to in their present professional self-understanding. At any rate, these professional self-contradictions deserve further attention and reflection, if not improvements.

Incidentally, our results should be interpreted with some methodological limitations. First of all, Korean respondents could not represent the whole of Korean psychiatric professionals. To grasp as well as generalize Korean psychiatric staffs' personal values and attitudes towards religious or spiritual aspects, further nationwide studies are needed. And also, regardless using nonparametric tests, the two national groups are significantly different in their demographical cha- 
racteristics. Therefore, our results could be affected by potentially different subgroups with untypical properties. In further processes and researches, more detailed analyses should be done.

\section{Conclusions}

The comparison of German and Korean psychiatric staff with regard to their personal religious and spiritual values and to their attitudes about dealing with religious or spiritual issues of their patients has shown significant differences between these modern secular societies with different histories, traditions and cultures. Above all, Korean psychiatric staff reports much more distance to such topics than does German staff. Some meaningful contradictions, inter alia in consideration of professional neutrality, were also found. Based on our findings, we highly recommend that psychiatric and psychotherapeutic professionals need to be aware of their own explicit and implicit religious, spiritual and personal beliefs, esp. in their communication with patients as whole persons. These beliefs are part of staffs' attitudes and of their counter-transferences. It would be against professional ethics to exclude these relevant aspects of one's own and patients' behaviors: 1) for scientific reasons in what are called "behavioral sciences", 2) for treatment reasons as they are potentially relevant factors and 3) for the goal of treatment which is the improvement of health and quality of life of the patients.

To better understand these results and their consequences for the patients, more cross-cultural research and in-depth analyses are needed. The readiness to adequately integrate religious or spiritual aspects into a wholistic perception and treatment of patients with their disorders continues to be a challenge to mental health professionals in both countries and beyond.

\section{Acknowledgements}

We are very thankful to the Chair-Professor J. Park (Daegu Catholic University Hospital), who conscientiously reviewed the translated questionnaire and by his friendly support facilitated a successful contact with psychiatric clinics. We also thank all the clinics and their staffs who supported our research by their valuable participation.

In part, this paper was supported by the National Research Foundation of Korea Grant funded by the Korean Government (2016SIA3A294944). For the rest, the paper was funded by own resources of the department of Caritas Science and Christian Social Work at Freiburg University.

\section{Conflicts of Interest}

The authors declare no conflicts of interest regarding the publication of this paper.

\section{References}

[1] Cobb, M.R., Puchalski, C.M. and Rumbold, B. (eds.) (2012) Oxford Textbook of Spirituality in Healthcare. Oxford University Press, Oxford. 
https://doi.org/10.1093/med/9780199571390.001.0001

[2] Koenig, H.G., King, D.E. and Carson, V.B. (Eds.) (2012) Handbook of Religion and Health. $2^{\text {nd }}$ Edition, Oxford University Press, Oxford.

[3] Koenig, H.G., McCullough, M.E. and Larson, D.B. (Eds.) (2001) Handbook of Religion and Health. $1^{\text {st }}$ Edition, Oxford University Press, Oxford.

[4] Huguelet, P. and Koenig, H.G. (Eds.) (2009) Religion and Spirituality in Psychiatry. Cambridge University Press, New York. https://doi.org/10.1017/CBO9780511576843

[5] Reiser, F. (2018) Menschen mehr gerecht werden: Zur Religiosität und Spiritualität von Patientinnen und Patienten in Psychiatrie und Psychotherapie. Echter Verlag, Würzburg.

[6] Juckel, G., Hoffmann, K. and Walach H. (Eds.) (2018) Spiritualität in Psychiatrie und Psychotherapie. Pabst Science Publishers, Lengerich.

[7] Hofmann, L. and Heise, P. (2017) Spiritualität und spirituelle Krisen. Handbuch zu Theorie, Forschung und Praxis, Schattauer, Stuttgart.

[8] Lee, E.M., Zahn, A. and Baumann, K. (2015) How Do Psychiatric Staffs Approach Religiosity/Spirituality in Clinical Practice? Differing Perceptions among Psychiatric Staff Members and Clinical Chaplains. Religions, 6, 930-947. https://doi.org/10.3390/rel6030930

[9] Lee, E.M., Zahn, A. and Baumann, K. (2011) Religion in Psychiatry and Psychotherapy? A Pilot Study: The Meaning of Religiosity/Spirituality from Staff's Perspective in Psychiatry and Psychotherapy. Religions, 2, 525-535.

https://doi.org/10.3390/rel2040525

[10] Utsch, M., Anderssen-Reuster, U., Frick, E., Gross, W., Murken, S., Schouler-Ocak, M. and Stotz-Ingenlath, G. (2017) Empfehlungen zum Umgang mit Religiosität und Spiritualität in Psychiatrie und Psychotherapie. Positionspapier der DGPPN. Spiritual Care, 6, 141-146. https://doi.org/10.1515/spircare-2016-0220

[11] Koenig, H.G. and Büssing, A. (2010) The Duke University Religion Index (DUREL): A Five-Item Measure for Use in Epidemological Studies. Religions, 1, 78-85. https://doi.org/10.3390/rel1010078

[12] Storch, E.A., Roberti, J.W., Heidgerken, A.D., Storch, J.B., Lewin, A.B., Killiany, E.M., Baumeister, A.L., Bravata, E.A. and Geffken, G.R. (2004) The Duke Religion Index: A Psychometric Investigation. Pastoral Psychology, 53, 175-181.

https://doi.org/10.1023/B:PASP.0000046828.94211.53

[13] Curlin, F.A., Lawrence, R.E., Odell, S., Chin, M.H., Lantos, J.D., Koenig, H.G. and Meador, K.G. (2007) Religion, Spirituality, and Medicine: Psychiatrists' and Other Physicians' Differing Observations, Interpretations, and Clinical Approaches. American Journal of Psychiatry, 164, 1825-1831. https://doi.org/10.1176/appi.ajp.2007.06122088

[14] Curlin, F.A., Odell, S.V., Lawrence, R.E., Chin, M.H., Lantos, J.D., Meador, K.G. and Koenig, H.G. (2007) The Relationship between Psychiatry and Religion among U.S. Physicians. Psychiatric Services, 58, 1193-1198.

https://doi.org/10.1176/ps.2007.58.9.1193

[15] Curlin, F.A., Chin, M.H., Shellergren, S.A., Roach, C.J. and Lantos, J.D. (2006) The Association of Physicians' Religious Characteristics with Their Attitudes and Self-Reported Behaviors Regarding Religion and Spirituality in the Clinical Encounter. Medical Care, 44, 446-453. https://doi.org/10.1097/01.mlr.0000207434.12450.ef 
[16] Kørup, A.K., Christensen, R., Nielsen, C.T., Søndergaard, J., Alyousefi, N.A., Lucchetti, G., Baumann, K., Lee, E., Karimah, A., Ramakrishnan, P., Frick, E., Büssing, A., Schousten, E. and Hvidt, N.C. (2017) The International NERSH Data Pool: A Methodological Description of a Data Pool of Religious and Spiritual Values of Health Professionals from Six Continents. Religions, 8, 24. https://doi.org/10.3390/rel8020024

[17] Hvidt, N.C., Kørup, A.K., Curlin, F.A., Baumann, K., Frick, E., Søndergaard, J., Nielsen, J.B., Christensen, R., Lawrence, R., Lucchetti, G., Ramakrishnan, P., Karimah, A., Schulze, A., Wermuth, I., Eglin, M., Opsahl, T. and Büssing, A. (2016) The NERSH International Collaboration on Values, Spirituality and Religion in Medicine: Development of Questionnaire, Description of Data Pool, and Overview of Pool Publications. Religions, 7, 107. https://doi.org/10.3390/rel7080107

[18] Lee, E.M., Zahn, A. and Baumann, K. (2014) Religiosity/Spirituality and Mental Health: Psychiatric Staff's Attitudes and Behaviors. Open Journal of Social Sciences 2, 7-13. https://doi.org/10.4236/jss.2014.211002

[19] Lee, E.M. (2014) Religiosität bzw. Spiritualität in Psychiatrie und Psychotherapie. Ihre Bedeutung für psychiatrisches Wirken aus der Sicht des psychiatrischen Personals anhand einer bundesweiten Personalbefraung. Echter Verlag, Würzburg.

[20] Baumann, K. (2012) The Birth of Human Sciences, Especially Psychology. In: Gilbert, P., Ed., L' uomo moderno e la Chiesa-Atti del Congresso (Analecta Gregoriana, 317), Gregorian \& Biblical Press, Rome, 391-408. 